\title{
An integrative review on patient inflicted violence among mental health nurses
}

\author{
Mohammed Hamdan Alshammari* \\ Mental Health Nursing Department, College of Nursing, University of Hail, Hail city, Saudi Arabia
}

Received: August 29, 2018

Accepted: November 13, $2018 \quad$ Online Published: November 15, 2018

DOI: $10.5430 /$ cns.v7n1p62

URL: https://doi.org/10.5430/cns.v7n1p62

\begin{abstract}
Workplace violence can be in the form of aggression, harassment or simply physical infliction of harm towards nurses. It can arise from many sources but primarily they are patient inflicted violence in different forms. It can be a physical violence, emotional or a combination of both. Incidence of violence towards health care professionals is a recognized global public health issue. Previous studies have already suggested that health care professionals, particularly nurses, have a higher risk of experiencing workplace violence than other professionals. This integrative review looked into the violence where patients are the primary source, as well as the types and impact of violence amongst psychiatric mental health nurses happening worldwide. Further, it looked into the nurses' road to recovery from the experience of violence and what hospitals and facilities are advocating in stopping these events or at least minimizing the frequency of such acts. Published studies considered in this review found that nurses' experienced physical pain, fear, anxiety, frustration, distress, resentment, apathy, job dissatisfaction and anger following the violent incident. Nurses after their exposure to a series of violence from their patients' experience dramatic changes in their well-being.
\end{abstract}

Key Words: Workplace violence, Aggression towards nurses, Mental health nurses violence, Aggression and violence

\section{INTRODUCTION}

Aggression and/or violence towards nurses may arise from many sources but primarily they are caused or inflicted by the mental health patients. Workplace violence towards health care professionals is a recognized global public health issue. Previous studies have already suggested that health care professionals, particularly nurses, have a higher risk of experiencing workplace violence than other professionals. ${ }^{[1]}$

Nurses experience different kinds of violence in the workplace. Several studies showed that nurses in psychiatric facilities experience physical, emotional, and verbal violence. ${ }^{[2]}$ Some studies even included sexual violence as a type of violence experienced by mental health nurses. ${ }^{[3]}$ Among the different forms of violence, the most common is physical violence. ${ }^{[3]}$

A violence inflicted to another person such as a patient to a nurse can be classified either as static or dynamic. These two types of violence are classified either because of the factors associated with it or the influence of the factors in its occurrence. When the cause of the violence is innate to the person and no clinical reason can be attributed to it, it is referred to as static factor of violence while dynamic risk factor is the exact opposite of a static wherein the factor leading to the violence can be changed through some medical procedures and interventions. An example of static risk factor of violence is the person prior mental health disorder while a current mental health problem like depression can become a

\footnotetext{
*Correspondence: Mohammed Hamdan Alshammari; Email: dr.mh.alshammari@ gmail.com; Address: Bldg. 9, College of Nursing, University of Hail, Baqaa Rd., Hail city, Saudi Arabia.
} 
dynamic risk factor. ${ }^{[4]}$

A study conducted in Iran manifested the need for nurses, psychiatric nurses in particular, to be vigilant as they provide care to their patients. This can be realized through in-service education and retraining by the hospital administration to all mental health staff. It highlighted the importance of active listening and assertive involvement in the care of psychiatric patients as it allows a more harmonious interaction between a patient and a nurse thus minimizing occurrence of violent behaviors. ${ }^{[5]}$ Nurses suffer consequential effects of experiencing violence in the workplace. Among the consequences of exposure to these types of violence are physical pain, emotional exhaustion and psychological distress. ${ }^{[6]}$ Further, nurses exposed to violence from patients also experienced negative feelings of fear, anger and frustration, despair, helplessness and hopelessness, apathy, desensitization, resentment and job dissatisfaction. These experiences of aggression and violence from patients lead to ineffective coping mechanisms. Psychiatric nurses' ineffective coping mechanisms include substance abuse, absenteeism, and violence in the form of retaliation, resentment, and apathy. ${ }^{[7]}$

Although there is a plethora of studies related to violence and aggression in the workplace, however, there is presently no comprehensive integrative review of these papers, at least within the past 10 years. Further, reviews conducted on violence among nurses focused on either Emergency Room nurses, nurses in various clinical settings or other members of the healthcare team. Few reviews were conducted to focus specifically on violence involving psychiatric nurses as well as the impact, types and the source of violence incurred by their patients and their road to recovery and acceptance. Therefore, it is timely and relevant to identify and examine what is known about this topic.

\section{METHODOLOGY}

\subsection{Aims and objectives}

The aim of this integrative review was to understand the broad picture of violence experienced by mental health nurses in their workplaces. Specifically to:

(1) Determine the prevalence and incidence of violence;

(2) Identify the types of patient-inflicted violence;

(3) Examine the impact of violence to the nurses;

(4) And recognize the interventions (e.g, rehabilitation, therapies) to minimize the impact of violence to their wellbeing.

This review utilized the integrative review framework outlined by Whittemore \& Knafl. ${ }^{[8]}$ This integrative review method is an approach that allows for the combination of diverse methodologies. ${ }^{[8]}$ As a methodological process, it is increasingly acknowledged as an appropriate strategy to present the state of the science, contribute to theory development, and inform and influence evidenced-based practice and policy on this topic (see Table 1).

An extensive literature search was done in six (6) online databases namely PubMed, CINAHL, Ebsco, Medline Plus, Web of Science and ProQuest. A total of 1,450 studies were initially retrieved from the electronic search databases.

\subsection{Inclusion and exclusion criteria}

For final inclusion in the review, the studies should meet the following criteria: the study should be from year 2008-2018; the study should be discussing about violence and aggression towards nurses in the psychiatric facility with focus on: (1) incidence and prevalence of violence; (2) type (e.g, physical) and source of violence are the patients; (3) impact of violence to the nurses; (4) intervention done after the experience of violence.

Full research papers written in English, published from 2008 to 2018, pertaining to the experiences of psychiatric nurses of violence in the workplace were included in this review. The search terms used in this review are "nurse violence", "nurse aggression", "psychiatric nurses", "mental health nurse", "workplace violence". Studies that are not written in English, do not meet all the criteria set and have no full copy available were excluded. A total of 19 papers that fit the inclusion criteria were included, analyzed and subsequently presented in this review.

\subsection{Quality appraisal}

Quality of the research was appraised with reference to the Critical Appraisal Skills Programme (CASP) research checklists. ${ }^{[9]}$ Papers were not excluded on the basis of their quality assessment. Instead, the purpose was to allow overall conclusions to be drawn as to the strength of evidence that exists. The quality of research was graded as moderately good in the scale and is diverse in sources and discussion.

\subsection{Data synthesis and presentation}

The data of each 19 studies were tabulated and presented clearly for easy comprehension and presented in the tables divided into author, year and country; study aim, sample and instrument used, design and analysis of data and the last column presents the significant findings of the study. Of the 19 studies, all discussed about the experience of violence in the workplace of psychiatric mental health nurses from their patients and the event occurred in the mental health unit of the hospital. The included studies are evenly distributed in terms of geographical boundaries in almost all continents (see Table 2). 
Table 1. Framework of integrative review according to Whittmore and Knafl ${ }^{[8]}$

\begin{tabular}{|c|c|}
\hline Stage of Review & Illustration of Decision and Issues \\
\hline Problem Identification & $\begin{array}{l}\text { Recent reports on the plight of nurses around the world showed that violence and aggression in the hospital } \\
\text { settings is still prevalent and the rate is increasing. Studies show that the two areas in the hospital where this } \\
\text { commonly occur are the emergency department and the psychiatric ward or psychiatric hospitals. Hundreds of } \\
\text { studies have been published on the occurrences of violence in psychiatric hospitals where the source of violence } \\
\text { can be the patient, the patient's relatives, nurses or colleagues and even doctors and other members of the allied } \\
\text { health profession. With these many studies, there were only a small percentage of published reviews and if there } \\
\text { are, they were published decade ago. Thus, this review identified studies } 10 \text { years back from } 2018 \text { and determined } \\
\text { some aspects on the topic of violence involving psychiatric mental health nurses on the following grounds: } \\
\text { prevalence and incidence of violence; type and source of violence; impact of violence; and intervention after the } \\
\text { violence. }\end{array}$ \\
\hline Literature Search & $\begin{array}{l}\text { With the idea in mind of what to search for and guided by the following criteria; the study should be from years } \\
\text { 2008-2018, the study should be discussing about violence in terms of prevalence and incidence, type and source, } \\
\text { impact and intervention after the violence. The subject or sample of the study should be psychiatric mental health } \\
\text { nurses and the setting should be in a psychiatric facility which can be a ward or unit in a hospital, nursing home or } \\
\text { a tertiary specialty hospital for psychiatric patients only. Studies that do not fall to these criteria are excluded but } \\
\text { may form part of the literature discussion or background of the study. The search databases utilized were } \\
\text { CINAHL, PubMed, ProQuest, Ebsco, Web of Science and Medline Plus. The keywords used are 'nurse violence', } \\
\text { 'nurse aggression', 'psychiatric nurses', 'mental health nurse', 'workplace violence'. }\end{array}$ \\
\hline Data Evaluation & $\begin{array}{l}\text { Initially there were } 1,450 \text { studies searched for using the keywords. After the initial review and analysis, only } 800 \\
\text { studies remained. Subsequently, after more thorough analysis, review, and using the criteria mentioned } \\
\text { previously, only } 19 \text { studies were included for final presentation and inclusion in this integrative review. }\end{array}$ \\
\hline Data Analysis & $\begin{array}{l}\text { The } 19 \text { studies included provide different perspectives of the occurrence and violence in the clinical setting of } \\
\text { various psychiatric hospitals around the world involving nurses. Incidents of violence involving psychiatric } \\
\text { nurses in their workplaces know no culture, religion or geographical boundaries. Some of these violent episodes } \\
\text { projected towards nurses took place in the USA, Taiwan, China, United Kingdom, Japan, Italy, Israel, Iran } \\
\text { among others. Each study was carefully examined, read and analyzed to determine its accuracy in terms of the } \\
\text { criteria set for this review. Studies that are similar in scope and topic however do not discuss psychiatric nurses as } \\
\text { samples or the locale is not a psychiatric facility were excluded. However, the essential ideas in these excluded } \\
\text { studies were taken to form part of the background and discussion. }\end{array}$ \\
\hline Presentation & $\begin{array}{l}\text { A tabular format of presentation of the } 19 \text { studies arranged from } 2008 \text { to } 2018 \text { is contained in this review. Each } \\
\text { study included was discussed and presented according to the following contents; the author/s, year and country of } \\
\text { the study, the aim, sampling method and instrument used, design and analysis of the data and lastly, the } \\
\text { significant findings. }\end{array}$ \\
\hline
\end{tabular}

\section{RESUlts}

Electronic databases were searched and yielded a total of 1,450 titles and abstracts. After the removal of duplicates and abstracts, 800 papers remained and were read in full. Of these, 781 were then excluded as a result of the criteria specified above not being met. The remaining 19 papers which explored aggression and violence towards mental health nurses in their workplaces were included in the final review (see Figure 1).

The 19 retrieved and downloaded studies from various countries and mental health facilities present different treatments of data, methods, instruments used as well as significant findings. However, they share a common component, which is that violence among mental health nurses come from patients and the prevalence of these violence is worth discussing. Other studies presented the road nurses undertake towards full recovery from the experience and the help they get from the hospital and other organizations.

One of the most important criteria in the search for the studies is the finding/s of the study. The findings should be discussing about the kinds and the source of violence, the impact of the violence and the events in that followed after the incident and how nurses are recovering from the experience. There were various methodologies utilized by the authors of the 19 final studies included in this review. These methods are through survey questionnaire, exploratory method, crosssectional studies, prospective studies, the use of face-to-face interview either alone or in combination of other methods and correlational analysis. Some methods are even aimed at creating a theory through explorative and descriptive methods while one of study used phenomenological design to capture the very essence and meaning of the participants' experience. 
Table 2. Profile of studies (2008-2018) ( $\mathrm{n}=19)$

\begin{tabular}{|c|c|c|c|c|}
\hline & $\begin{array}{l}\text { Author/s, Year, } \\
\text { Country }\end{array}$ & Aim/s, Sampling Method, Instrument & $\begin{array}{l}\text { Design, Treatment of } \\
\text { Data }\end{array}$ & Significant Findings \\
\hline 1 & $\begin{array}{l}\text { Chen WC, et al. } \\
\text { 2008, Taiwan }\end{array}$ & $\begin{array}{l}\text { This study determined the prevalence of workplace } \\
\text { violence and its risk factors for employees at a psychiatric } \\
\text { hospital in Taiwan. A questionnaire developed by } \\
\text { ILO/ICN/WHO/PSI was first translated and validated. It } \\
\text { was then used to survey the prevalence of workplace } \\
\text { violence in the last } 12 \text { months experienced by all nursing } \\
\text { aides, nurses, and clerks at the hospital. }\end{array}$ & $\begin{array}{l}\text { Quantitative; Use of a } \\
\text { Survey Questionnaire }\end{array}$ & $\begin{array}{l}\text { The one-year prevalence rates of physical violence (PV), verbal abuse, } \\
\text { bullying/mobbing, sexual harassment, and racial harassment were } 35.1 \% \text {, } \\
50.9 \%, 15.8 \%, 9.5 \% \text {, and } 4.5 \% \text {, respectively. The prevalence of } \mathrm{PV} \text { at this } \\
\text { hospital was higher than that reported by other countries for the health } \\
\text { sector. }\end{array}$ \\
\hline 2 & $\begin{array}{l}\text { Chapman R, et } \\
\text { al. } 2010 \text {, } \\
\text { Australia }\end{array}$ & $\begin{array}{l}\text { Identified how nurses in several areas of a hospital setting } \\
\text { adapted to workplace violence and review past research } \\
\text { studies which has been previously unexamined. }\end{array}$ & $\begin{array}{l}\text { Qualitative; Exploratory } \\
\text { study }\end{array}$ & $\begin{array}{l}\text { Participants were found to use the cognitive processes of finding meaning, } \\
\text { gaining mastery and enhancing the self to adapt to workplace violence. } \\
\text { Critical incident debriefing may facilitate the nurse victim's psychological } \\
\text { recovery following an episode of workplace violence. }\end{array}$ \\
\hline 3 & $\begin{array}{l}\text { Franz S, et al. } \\
\text { 2010, Germany }\end{array}$ & $\begin{array}{l}\text { Nurses and health care workers from two nursing homes, } \\
\text { a psychiatric clinic and a workshop for people with } \\
\text { disabilities were interviewed using a standardized } \\
\text { questionnaire. The sample covered } 123 \text { individuals } \\
\text { (response rate } 38.8 \% \text { ). The survey assessed the frequency, } \\
\text { the type and the consequences of aggressive behavior, and } \\
\text { social support in connection with coping with aggression } \\
\text { in the workplace. }\end{array}$ & $\begin{array}{l}\text { Quantitative; Cross } \\
\text { sectional study } \\
\text { retrospective survey. }\end{array}$ & $\begin{array}{l}\text { Physical aggression more frequently occurred in nursing homes ( } 83.9 \% \text { of } \\
\text { the employees) and verbal aggression was more common in the psychiatric } \\
\text { clinic ( } 96.7 \% \text { of the employees). The proportion of the individuals affected } \\
\text { in the workshop for people with disabilities was lower ( } 41.9 \% \text { and } 77.4 \% \\
\text { respectively). The incidents impaired the physical }(55 \%) \text { and emotional } \\
\text { well-being }(77.2 \%) \text { of the employees. }\end{array}$ \\
\hline 4 & $\begin{array}{l}\text { Chen WC, et al. } \\
\text { 2011, Taiwan }\end{array}$ & $\begin{array}{l}\text { Seventy-seven volunteers were recruited to complete a } \\
\text { baseline questionnaire. Participants then used a } \\
\text { designated Web site to report violent incidents they } \\
\text { encountered during a 6-month period. A generalized } \\
\text { estimating equation was used for data analysis. A total of } \\
74 \text { members completed the study; } 456 \text { events were } \\
\text { reported. }\end{array}$ & $\begin{array}{l}\text { Quantitative; Prospective } \\
\text { follow-up study to explore } \\
\text { incidence and risk factors } \\
\text { related to workplace } \\
\text { violence towards nurses. }\end{array}$ & $\begin{array}{l}\text { The incidence rates of various types of violence are reported in this paper. } \\
\text { Risk factors for violence included short duration of employment, marital } \\
\text { status, and a high level of anxiety. Strategies to reduce future violence from } \\
\text { psychiatric patients include pre-placement education that targets this } \\
\text { high-risk group of nurses and efforts to reduce the staff anxiety levels. }\end{array}$ \\
\hline 5 & $\begin{array}{l}\text { Magnavita N. } \\
\text { 2011, Italy }\end{array}$ & $\begin{array}{l}\text { To determine the frequency of violent incidents against } \\
\text { workers in a residential rehabilitation unit during medical } \\
\text { examinations in the workplace between } 1996 \text { and 2009. A } \\
\text { violence prevention program that included educational, } \\
\text { organizational, and medical measures implemented } \\
\text { among nurses in } 2002 \text {. }\end{array}$ & $\begin{array}{l}\text { Quantitative and } \\
\text { Qualitative: Using survey } \\
\text { questionnaire and } \\
\text { interview }\end{array}$ & $\begin{array}{l}\text { Interrupted time series analysis showed that the aggression trend prior to } \\
\text { intervention was flat (beta3 }=-0.004 ; S D=0.003 ; p=.241 \text { ), while there } \\
\text { was a significant drop in aggressions after the intervention (beta3 } 3=-0.149 \text {; } \\
S D=0.018 ; p<.0001 \text { ). No late increase in trend was observed in the } \\
\text { post-intervention period (beta3 }=-0.006 ; S D=0.004 ; p=.175 \text { ). The } \\
\text { program contributed to reducing violence in the workplace. }\end{array}$ \\
\hline 6 & $\begin{array}{l}\text { Zuzelo PR, et al. } \\
\text { 2012, USA }\end{array}$ & $\begin{array}{l}\text { This study explored nursing staff's individual and group } \\
\text { responses to violent incidents performed by patients } \\
\text { against caregivers through focus group discussion to } \\
\text { collect data from professional nurses and behavioral } \\
\text { health associations }(\mathrm{N}=19) \text { recruited from urban, } \\
\text { inpatient psychiatric unit. }\end{array}$ & $\begin{array}{l}\text { Qualitative: Face-to-face } \\
\text { interview and focus group } \\
\text { discussion }\end{array}$ & $\begin{array}{l}\text { Sharing information about violence, intervening therapeutically, } \\
\text { intervening non-therapeutically, recognizing team influences, } \\
\text { experiencing emotions following violence, and understanding the work } \\
\text { environment comprised the major themes of the experience. }\end{array}$ \\
\hline 8 & $\begin{array}{l}\text { Khoshknab MF, } \\
\text { et al. 2012, Iran }\end{array}$ & $\begin{array}{l}\text { This study determined the workplace violence in Razi } \\
\text { Psychiatric Center, Tehran, Iran. They were enrolled } \\
\text { using the International Workplace Violence } \\
\text { questionnaire. Among } 385 \text { nurses of this ward, } 200 \\
\text { subjects completed the questionnaire using a simple } \\
\text { random sampling method with a response rate of } 91.5 \% \text {. }\end{array}$ & $\begin{array}{l}\text { Quantitative; } \\
\text { Cross-sectional design } \\
\text { using survey questionnaire }\end{array}$ & $\begin{array}{l}\text { The prevalence of workplace violence was } 71 \% \text { including mental }(93.4 \%) \\
\text { and physical violence }(71.6 \%) \text {. Verbal and sexual violence occurred in } \\
19.1 \text { and } 5.5 \% \text { of subjects, respectively. The } 62.3 \% \text { of the nurses did not } \\
\text { report violence because they considered it useless ( } 55.3 \% \text { ) or did not } \\
\text { believe to be important }(42.1 \%) \text {. The } 61.2 \% \text { believed to the necessity of } \\
\text { training courses while } 72.7 \% \text { had completed these courses and } 59.6 \% \\
\text { believed to a reporting system. The need to security guard }(56.8 \%) \text {, taking } \\
\text { security actions in wards ( } 67.8 \%) \text { and training of staffs }(68.9 \%) \text { were the } \\
\text { most important preventive measures reported to be effective for workplace } \\
\text { violence }\end{array}$ \\
\hline 9 & $\begin{array}{l}\text { Baby M, et al. } \\
\text { 2014, New } \\
\text { Zealand }\end{array}$ & $\begin{array}{l}\text { The aim of the study was to explore and describe } \\
\text { psychiatric mental health nurses' experiences of patient } \\
\text { assaults through interview of nurses working in the } \\
\text { psychiatric facility. }\end{array}$ & $\begin{array}{l}\text { Qualitative: Exploratory } \\
\text { study using thematic } \\
\text { analysis and coding }\end{array}$ & $\begin{array}{l}\text { The paper concludes that while healthcare employers need to provide } \\
\text { better support services to the healthcare professionals who are assaulted, } \\
\text { the legal system also needs to acknowledge that assaults against } \\
\text { nurses are a violation of human rights and violence should not to be } \\
\text { tolerated as part of working in mental healthcare settings. }\end{array}$ \\
\hline 10 & $\begin{array}{l}\text { Itzhaki M, et al. } \\
\text { 2015, Israel }\end{array}$ & $\begin{array}{l}\text { The sample consisted of mental health nurses }(\mathrm{n}=118) \\
\text { working in a large mental health centre in Israel. Verbal } \\
\text { violence by patients was reported by } 88.1 \% \text { of the nurses, } \\
\text { and } 58.4 \% \text { experienced physical violence in the past year. }\end{array}$ & $\begin{array}{l}\text { Quantitative: Descriptive } \\
\text { cross-sectional design } \\
\text { using inferential statistics }\end{array}$ & $\begin{array}{l}\text { Physical and verbal violence towards nurses was correlated with job stress, } \\
\text { and life satisfaction was correlated with Post-Trauma Growth or PTG and } \\
\text { staff resilience. Linear regression analyses indicated that life satisfaction } \\
\text { was mainly affected by PTG, staff resilience, and job stress, and less by } \\
\text { exposure to verbal and physical violence. The present study is the first to } \\
\text { show that, although mental health nurses are frequently exposed to } \\
\text { violence, their life satisfaction is affected more by staff resilience, PTG, } \\
\text { and job stress than by workplace violence. }\end{array}$ \\
\hline 11 & $\begin{array}{l}\text { Bilici R, et al. } \\
\text { 2016, Turkey }\end{array}$ & $\begin{array}{l}\text { Explored the rates of exposure to violence among } \\
\text { physicians, nurses, and other health care staff members } \\
\text { working at the locked psychiatric clinics, to examine the } \\
\text { quantity and types of violence exposed, and to compare } \\
\text { occupational groups by the level of exposure to violence. }\end{array}$ & $\begin{array}{l}\text { Quantitative; } \\
\text { Cross-sectional design }\end{array}$ & $\begin{array}{l}\text { The survey found that } 87.6 \% \text { of staff members viewed security measures } \\
\text { insufficient. It is considered by the authors that preventive actions should } \\
\text { be taken to reduce the risk of exposure to violence against the staff } \\
\text { members working at the locked psychiatric clinics. }\end{array}$ \\
\hline
\end{tabular}


Table 2. (continued.)

\begin{tabular}{|c|c|c|c|c|}
\hline & $\begin{array}{l}\text { Author/s, Year, } \\
\text { Country }\end{array}$ & Aim/s, Sampling Method, Instrument & $\begin{array}{l}\text { Design, Treatment of } \\
\text { Data }\end{array}$ & Significant Findings \\
\hline 12 & $\begin{array}{l}\text { Bimenyimana E, } \\
\text { et al. 2016, } \\
\text { South Africa }\end{array}$ & $\begin{array}{l}\text { The purpose of this article was to describe the process that } \\
\text { was followed in developing, describing and evaluating a } \\
\text { model that could be used as a framework of reference to } \\
\text { facilitate the effective management of aggression as an } \\
\text { integral part of the mental health of PNs (psychiatric } \\
\text { nurses). }\end{array}$ & $\begin{array}{l}\text { Qualitative; A } \\
\text { theory-generative, } \\
\text { qualitative, exploratory, } \\
\text { descriptive and contextual } \\
\text { study design was used to } \\
\text { develop the model }\end{array}$ & $\begin{array}{l}\text { The conceptual framework may be able to assist (psychiatric nurses) or } \\
\text { PNs in managing aggression effectively, taking control of workplace } \\
\text { environment. }\end{array}$ \\
\hline 13 & $\begin{array}{l}\text { Ferri P, et al. } \\
\text { 2016, Italy }\end{array}$ & $\begin{array}{l}\text { Violent Incident Form was distributed to } 745 \\
\text { professionals (physicians, head nurses, nurses, nursing } \\
\text { assistants), who worked in } 15 \text { wards of a general hospital } \\
\text { in northern Italy. }\end{array}$ & $\begin{array}{l}\text { Quantitative } \\
\text { cross-sectional design } \\
\text { using correlation analysis }\end{array}$ & $\begin{array}{l}\text { The study suggests that violence is a significant phenomenon and that all } \\
\text { health workers, especially nurses, are at risk of suffering aggressive } \\
\text { assaults. Workplace Violence or WPV presented specific characteristics } \\
\text { related to the health care settings, where the aggression occurred. }\end{array}$ \\
\hline 14 & $\begin{array}{l}\text { Fujimoto H, et } \\
\text { al. 2017, Japan }\end{array}$ & $\begin{array}{l}\text { Psychiatric Visiting Nurses or PVNs were assessed using } \\
\text { a violence exposure questionnaire and the Impact of Event } \\
\text { Scale-Revised (IES-R-J); a measure of posttraumatic } \\
\text { distress. }\end{array}$ & $\begin{array}{l}\text { Qualitative: } \\
\text { Cross-sectional study } \\
\text { investigated violence } \\
\text { during visits and the } \\
\text { resulting psychological } \\
\text { effects for PVNs }\end{array}$ & $\begin{array}{l}\text { Forty-one ( } 41 \%) \text { of } 94 \text { participants had experienced violence during the } \\
\text { previous } 12 \text { months and } 49(53 \%) \text { over their entire career. The most } \\
\text { frequent violence was verbal abuse. Career length as a PVN and number of } \\
\text { visits per month were significantly positively associated with verbal abuse } \\
\text { during the previous } 12 \text { months }\end{array}$ \\
\hline 15 & $\begin{array}{l}\text { Hsiu-Fen H, et } \\
\text { al. 2017, Taiwan }\end{array}$ & $\begin{array}{l}\text { The aim of the authors in this study was to identify factors } \\
\text { associated with resilience that helped abused nurses face } \\
\text { and cope with violent events. Data were collected from } \\
\text { June } 2013 \text { to December 2013; } 272 \text { participants were } \\
\text { recruited from emergency rooms and psychiatric wards in } \\
\text { four hospitals in central Taiwan. }\end{array}$ & $\begin{array}{l}\text { Quantitative; } \\
\text { Cross-sectional study with } \\
\text { regression analysis }\end{array}$ & $\begin{array}{l}\text { Among these participants, } 230(84.6 \%) \text { met the inclusion criterion and } \\
\text { completed all questionnaires; } 69(30 \%) \text { of them reported having } \\
\text { experienced only verbal violence; } 46 \text { ( } 20 \%) \text { reported having experienced } \\
\text { only physical violence, and } 115(50 \%) \text { reported having experienced a } \\
\text { combination of verbal and physical violence. }\end{array}$ \\
\hline 16 & $\begin{array}{l}\text { Yang BX, et al. } \\
\text { 2018, China }\end{array}$ & $\begin{array}{l}\text { The study investigated the incidence, type, related factors, } \\
\text { and effects of workplace violence on mental health nurses } \\
\text { as well as identifying coping strategies. The researchers } \\
\text { designed workplace violence questionnaire and the } \\
\text { Maslach Burnout Inventory-General Survey were } \\
\text { distributed to nurses at a mental health hospital in Wuhan, } \\
\text { China. }\end{array}$ & $\begin{array}{l}\text { Quantitative; } \\
\text { Cross-sectional survey } \\
\text { using descriptive statistics }\end{array}$ & $\begin{array}{l}\text { Most nurses reported a high incidence of workplace violence }(94.6 \%) \text { in } \\
\text { the past year ranging from verbal aggression, sexual harassment, to } \\
\text { physical attack. The forms of violence significantly correlated with each } \\
\text { other }(r>0.5, p=.000) \text {. }\end{array}$ \\
\hline 17 & $\begin{array}{l}\text { Beryl R, et al. } \\
\text { 2018, United } \\
\text { Kingdom }\end{array}$ & $\begin{array}{l}\text { Interview transcripts were analyzed with the use of } \\
\text { interpretative phenomenological analysis, and the } \\
\text { findings presented within four superordinate themes } \\
\text { 'horror', 'balancing acts', 'emotional hard labour', and } \\
\text { 'the ward as a community'. }\end{array}$ & $\begin{array}{l}\text { Qualitative; } \\
\text { Phenomenological Study }\end{array}$ & $\begin{array}{l}\text { The findings suggest the importance of workforce development in terms of } \\
\text { allowing sufficient protected time for reflection and formulation (e.g. } \\
\text { within the format of group supervision or reflective practice), and for } \\
\text { staff-support mechanisms (e.g. clinical supervision, counseling, debriefs) } \\
\text { to be inbuilt into the ethos of a service, so as to provide proactive support } \\
\text { for staff 'on the frontline'. }\end{array}$ \\
\hline 18 & $\begin{array}{l}\text { Hsieh HF, et al. } \\
\text { 2018, Taiwan }\end{array}$ & $\begin{array}{l}\text { All participants were recruited from psychiatric wards of } \\
\text { six hospitals in Taiwan. The data were collected through } \\
\text { structured questionnaires from October 2013-March } 2014 \\
\text { and a total of } 278 \text { psychiatric wards nurses participated in } \\
\text { this study and completed all questionnaires. }\end{array}$ & $\begin{array}{l}\text { Quantitative: } \\
\text { Cross-sectional and } \\
\text { correlational study. }\end{array}$ & $\begin{array}{l}\text { Of all the assaulted psychiatric ward nurses, } 75.9 \% \text { had depressive } \\
\text { symptoms and those with higher family support had significantly lower } \\
\text { depressive symptoms. }\end{array}$ \\
\hline 19 & $\begin{array}{l}\text { Itzhaki M, et al. } \\
\text { 2018, Israel }\end{array}$ & $\begin{array}{l}\text { Data were collected from } 114 \text { mental health nurses ( } 49 / 63 \\
\text { M/F) who completed a self-administered questionnaire } \\
\text { examining violence exposure, ProQOL, and job stress. } \\
\text { This study was based on two aspects of ProQOL, the } \\
\text { positive compassion satisfaction, and the negative } \\
\text { compassion fatigue, with the aim of investigating the } \\
\text { relation of ProQOL to job stress and violence exposure at } \\
\text { a large mental health center. }\end{array}$ & $\begin{array}{l}\text { Quantitative: Survey } \\
\text { Questionnaire }\end{array}$ & $\begin{array}{l}\text { The results showed that during the last year, almost all nurses }(88.6 \%) \\
\text { experienced verbal violence, and more than half }(56.1 \%) \text { experienced } \\
\text { physical violence. Only } 2.6 \% \text { experienced no violence. ProQOL was not } \\
\text { associated with violence exposure but was reduced by work stress and by } \\
\text { previous exposure to violence; nurses who perceived their work as more } \\
\text { stressful had lower satisfaction from their work. }\end{array}$ \\
\hline
\end{tabular}

\section{Discussion}

\subsection{Incidence and prevalence}

This review revealed that younger and less experienced nurses were more at risk of violence in the workplace when compared with older and more experienced nurses. ${ }^{[10]}$ The studies of Tonso et al. showed that those between 20-29 years in practice reported experience of humiliating aggressive behavior on an average of 5.1 occasions while those in service for 30-39 years had an average of 2.5 experiences. Finally, those with between 10-19 years had an average of 2.38 occasions in one month. ${ }^{[1,3]}$

Some nurses have sustained minor injuries. This has resulted in missed days of work. Anderson and West ${ }^{[4]}$ found that half of nurses who are victims of violence either request for a leave of absence or resign totally from the job. Some even reported symptoms suggestive of post-traumatic stress disor- der (PTSD). Nurses working in the day shift had a slightly higher rate of verbal aggression than the evening shift. ${ }^{[10]}$ Weeks that had a higher percentage of patients with personality disorders were significantly associated with a higher risk of verbal aggression. Limit setting regarding behaviors or privileges were associated with a higher percentage of verbal aggression incidents (44\%) than physical aggression incidents (35\%). ${ }^{[11]}$

The incidence of physical assault ranged from as low as $20 \%$ in a cohort of Taiwanese nurses, to as high as $61.5 \%$ experienced by nurses in China. ${ }^{[10]}$ The perpetrator was most frequently a patient for victims of physical assaults. ${ }^{[1,3]}$ In most settings, male nurses were more likely to encounter physical assaults. ${ }^{[12]}$ The evidence also suggests that evening-shift nurses were more at risk of experiencing workplace aggression than day shift nurses. ${ }^{[10]}$ 


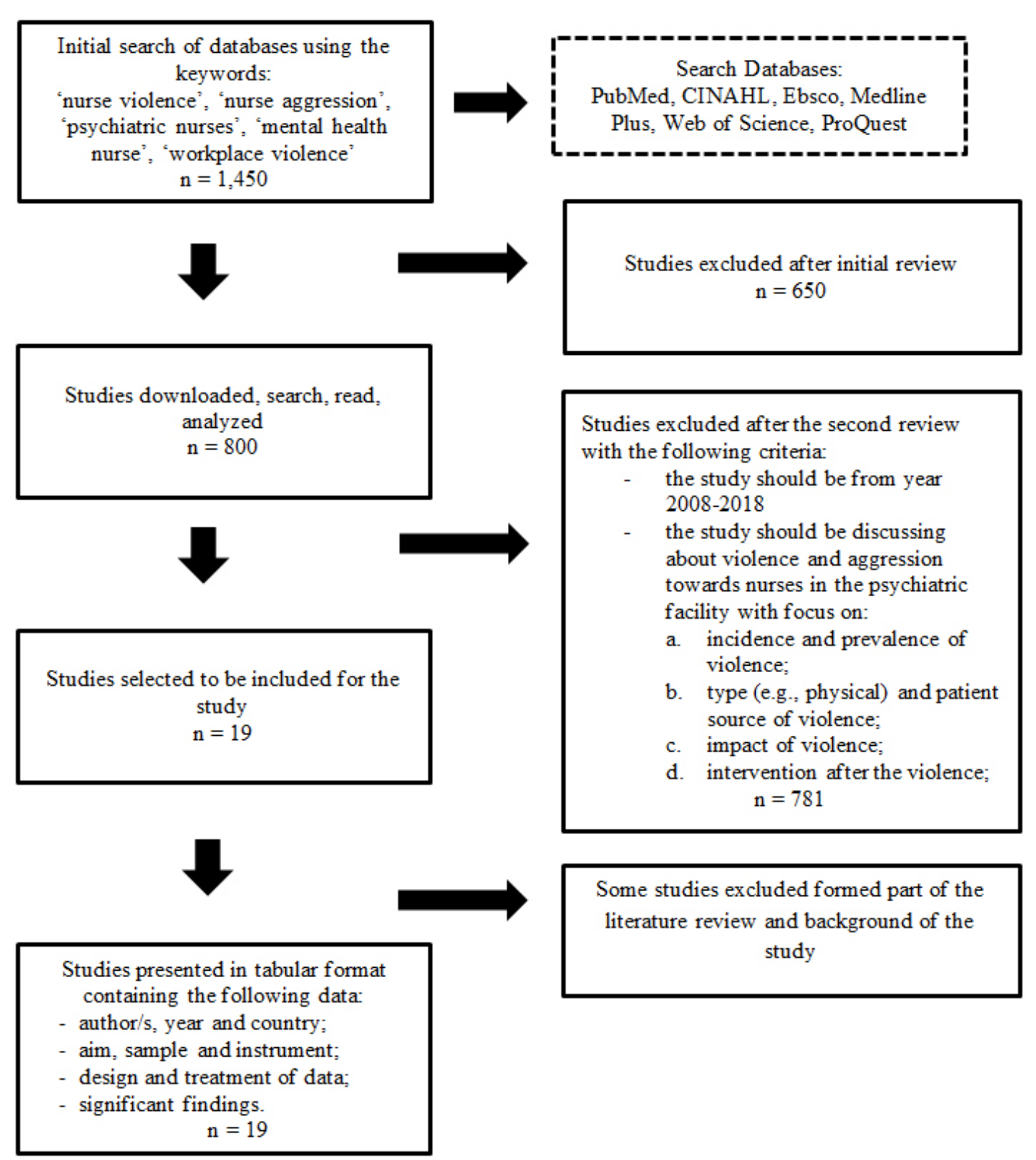

Figure 1. Flowchart of study selection of studies for inclusion in the integrative review

The weeks that had higher percentage of patients with personality disorders were significantly associated with higher risk of verbal and physical aggression. ${ }^{[13]}$ In the study of Anderson \& West, ${ }^{[4]}$ findings show that mentally committed individuals with disorders such as schizophrenia tend to become more violent compared with other patients committed under the same institution. However, the rate of violence involving patients with schizophrenia and other chronic mental disorders with organic causes is demographically not significant since admissions for these disorders are few. ${ }^{[4]}$

In terms of gender, female patients were just as likely as male patients to have been violent, and the characteristics of the violent attacks were the same for the two genders. ${ }^{[4,14]}$

Published by Sciedu Press
Moreover, younger patients were more likely to be violent than older patients, more frequently responsible for multiple violent incidents. ${ }^{[4,14]}$ In addition to the foregoing discussion, some risk factors for violence were identified among the patients that included variables such as short hospital stay, employment status, marital status and high level of anxiety. These factors were seen among the patients who commit violence against nurses more often than other patients. ${ }^{[15]}$

\subsection{Types and sources of violence}

Verbal abuse was the most commonly experienced form of violence by nurses in the mental healthcare setting. This is followed by physical violence and sexual harassment. High in- 
cidences of verbal abuse from patients or their relatives were evident in Taiwan, China, Australia, Ireland, New Zealand, and the United States of America. ${ }^{[1,3,10,11,16]}$ Common types of verbal abuse against nurses included yelling, being cursed at, being intimidated, being harassed with sexual language.

Chen et al. added that aside from verbal abuse, other types of abuse that exists include sexual harassment, bullying, mobbing and even racial harassment as reported by a study conducted in Taiwan using a questionnaire developed by the World Health Organization (WHO), International Council of Nurses (ICN) and other nursing organization. ${ }^{[17,18]}$

Patients with personality disorders were associated with a significantly ( $p$-value .004) higher risk for physical aggression. ${ }^{[10,19]}$ A study by Zeng et al. ${ }^{[10]}$ also showed that rates of physical incidents were significantly higher in evening than day shift. Assisting with activities of daily living had a higher percentage of physical aggression incidents (18\%) than verbal aggression incidents $(6 \%) .{ }^{[10,19]}$

\subsection{Impact of violence}

Nurses who continuously are faced with violence in the workplace would relate the feeling as unimaginable and few other even loss control of the situation and becomes fearful and severely anxious. Other nurses have difficulty concentrating on nursing tasks required and recourse to ineffective coping mechanisms such as poor food choices, substance abuse, and absenteeism as a result of experiencing violence. ${ }^{[13,20]}$

Nurses experience physical pain, fear, anxiety, frustration, distress, resentment, apathy, job dissatisfaction, and anger following a violent incident. ${ }^{[6,7,21-23]}$ As a result of violence, they notice some changes in their lives especially in the expression of their emotions as well as some physical manifestations of the incident such as reliving the traumatic event at some point. ${ }^{[20]}$

\subsection{Interventions and nurses' state of being}

One study conducted in Australia reported that some nurses who have been exposed to violence underwent cognitive therapy in finding meaning in the experience of violence, coping with the aftermath of the experience and regaining mastery of the environment which includes the workplace and finding strength to work and carry out the duties of a nurse in a normal state of mind and body as before the incident. ${ }^{[24]}$

On similar scale, this time the use of simulation, helped analyzed nurses' perceived preparedness towards an actual violent event occurring in their workplace sometime in the future. The simulation training test and classroom teaching test combined elicit a natural response in a person when faced with violence. These training methods were proven effective in deescalating the impact of violence to nurses. ${ }^{[25]}$ Similar study purported that the hospital management should take the lead in providing interventions like the previously mentioned ones towards their staff when they experience violence within the hospital premises. ${ }^{[26]}$

In Italy, an interventional program called Violence Prevention Program was implemented which included educational, organizational and medical measures among nurses that started in 2002. Using interrupted time series analysis, it was found that there was a significant drop in aggression after the intervention and contributed to the dramatic decrease of violence in the workplace. ${ }^{[27]}$ Any form of aggression and violence committed against a person is unlawful. Nurses, like any citizen of the state deserves to be legally protected and any harm inflicted to them is considered a human rights violation. $^{[21,22]}$

Nurses who are exposed either one time or in several occasions to violence should undergo debriefing and counselling when permitted to minimize the residual effect of the incident. ${ }^{[20]}$ Peer support is the most common support strategy. Other support strategies identified include clinical supervision, and critical incident stress debriefing related to factors: time of incident, appropriate utilization, interaction between individuals involved in the process. ${ }^{[4,21,22]}$ Some of the proven techniques and procedures to deescalate the impact of violence to nurses include verbalization of the event through active listening, assertiveness training and avoidance of the event or violence. ${ }^{[4]}$

\section{Conclusions}

The incidence of violence among mental health nurses is diverse and knows no cultural and geographical boundaries. Recovering from the impact of violence requires one's courage and resilience. A strong and willing workforce is needed to develop willingness for reflection on the impact of the experience and formulation of future actions to successfully manage or prevent its future occurrences. ${ }^{[28]}$

Due to the nature of the job, mental health nurses are exposed to future and ongoing violence from their patients. Several factors may interplay on the road to successful resolution of the inner conflict rooted from the frequent exposure to violence, thus, intervention programs are necessary to be adopted in the workplace so that nurses can built upon resilience and Post-Trauma Growth or PTG. ${ }^{[29,30]}$

While some clinical trials and published articles showed the effectiveness of reflective debriefing among healthcare workers such as nurses, the decision to undergo such treatment must be within the nurse' voluntary resolve or as required and provided by the organization's policies and by-laws. ${ }^{[5]}$

ISSN 2324-7940 E-ISSN 2324-7959 
In China, the Chinese version of the Psychosocial Safety Climate Scale or PSC-12 recommended the need to promote safety classes and trainings among nurses to minimize workplace violence or at least nurses will become more equipped in intervening such workplace events. ${ }^{[15]}$

Violence may occur, anywhere and anytime and no one is ever safe from experiencing it. Mental health nurses in particular work and provide care for people who may have experienced the worst form of violence at least once in their lifetime leading to their commitment in the mental health facility. Understanding the nature of the patient's condition would allow the nurse to have a better perspective of why violence in the workplace sometimes becomes a normal scene of the day and leave the workplace hoping that tomorrow will be a better workday and the duty to serve continue.

\section{CONFLiCTS OF INTEREST Disclosure}

The authors declare they have no conflicts of interest.

\section{REFERENCES}

[1] Tonso M, Prematunga R, Norris S, et al. Workplace Violence in Mental Health: A Victorian Mental Health Workforce Survey. International Journal of Mental Health Nursing. 2016; 25: 444-451. PMid: 27339029. https://doi.org/10.1111/inm. 12232

[2] Whittington R. Attitudes toward patient aggression amongst mental health nurses in the 'zero tolerance' era: associations with burnout and length of experience. Journal of Clinical Nursing. 2002; 11: 819-829. PMid: 12427188 . https://doi.org/10.1046/j.1365 $-2702.2002 .00659 . x$

[3] Tonso M, Prematunga R, Norris S, et al. Aggression and violence in mental health services: categorizing the experiences of Irish nurses. Journal of Psychiatric and Mental Health Nursing. 2016; 14: 120127.

[4] Anderson A, West S. Violence Against Mental Health Professionals: When the Treater Becomes the Victim. Innovations in Clinical Neuroscience. 2011; 8(3): 34-39. PMid: 21487544.

[5] Vahidi M, Ebrahimi H, Areshtanab HN, et al. Providing a Safe Environment in a Psychiatric Ward: Nurses and Vigilance in Iran. Issues Ment Health Nurs. 2018; 1-8. https ://doi.org/10.1080/0161 2840.2018 .1463326

[6] Nguluwe B, Havenga Y, Sengane M. Violence Experienced by Nurses Working in Acute Care Psychiatric Wards at a Gauteng Hospital. Africa Journal of Nursing and Midwifery. 2014; 16(1): 60-74. https://doi.org/10.25159/2520-5293/1488

[7] Bimenyimana E, Poggenpoel M, Myburgh C, et al. The lived experience by psychiatric nurses of aggression and violence from patients in a Gauteng psychiatric institution. Curationis. 2009; 32(3): 4-13. PMid: 20225739. https://doi.org/10.4102/curation is.v32i3. 1218

[8] Whittemore R, Knafl K. The integrative review: updated methodology. J Adv Nurs. 2005; 52(5): 546-553. PMid: 16268861. https: //doi.org/10.1111/j.1365-2648.2005.03621.x

[9] Pearce-Smith N. Critical Appraisal Skills Checklist. Feb 2012. Available from: https://casp-uk.net/

[10] Zeng JY, An FR, Xiang YT, et al. Frequency and risk factors of workplace violence on psychiatric nurses and its impact on their quality of life in China. Psychiatry Research. 2013; 210: 510-514. PMid: 23850435. https://doi.org/10.1016/j.psychres.2 013.06 .013

[11] Ridenour M, Lanza M, Hendricks S, et al. Incidence and risk factors of workplace violence on psychiatric staff. IOS Press. 2015; 51: 19-28. https://doi .org/10.3233/WOR-141894

[12] Lawoko S, Soares J, Nolan P. Violence towards psychiatric staff: a comparison of gender, job, and environmental characteristics in
England and Sweden. Work \& Stress. 2004; 18(1): 39-55. https : //doi.org/10.1080/02678370410001710337

[13] Bimenyimana E, Poggenpoel M, Temane A, et al. A model for the facilitation of effective management of aggression experienced by Psychiatric Nurses from patients in a psychiatric institution. Curationis. 2016; 39(1): e1-e9. PMid: 28155301. https ://doi.org/10 .4102 /curationis.v39i1.1676

[14] Cornaggia C, Beghi M, Pavone F, et al. Aggression in psychiatry wards: a systematic review. Psychiatry Research. 2011; 189: 1020. PMid: 21236497. https://doi.org/10.1016/j.psychres .2010 .12 .024

[15] Pien LC, Cheng Y, Cheng WJ. Psychosocial Safety Climate, Workplace Violence and Self-rated Health: a Multi-level Study among Hospital Nurses. J Nurs Manag. 2018. PMid: 30194879. https: //doi.org/10.1111/jonm.12715

[16] Hsieh HF, Chang SC, Wang HH. The relationships among personality, social support, and resilience of abused nurses at emergency rooms and psychiatric wards in Taiwan. Women \& Health. 2016. PMid: 26853374.

[17] Chen WC, Hwu HG, Kung SM, et al. Prevalence and determinants of workplace violence of health care workers in a psychiatric hospital in Taiwan. J Occup Health. 2008; 50(3): 288-293. PMid: 18408350. https://doi.org/10.1539/joh.L7132

[18] Chen WC, Sun YH, Lan T, et al. The incidence and risk factors of workplace violence towards female nurses reported via internet in an acute psychiatric hospital. Arch Environ Occup Health. 2011; 66(2): 100-106. PMid: 24484367. https://doi.org/10.1080/193382 44.2010 .511310

[19] Ridenour M, Lanza M, Hendricks S, et al. Incidence and risk factors of workplace violence on psychiatric staff. PMC. 2015; 51(1): 19-28. https://doi .org/10.3233/WOR-141894

[20] Stevenson K, Jack S, O'Mara L, et al. Registered nurses' experiences of patient violence on acute care psychiatric inpatient units: an interpretive descriptive study. BMC Nursing. 2015. PMid: 25999795 https://doi.org/10.1186/s12912-015-0079-5

[21] Baby M, Carlyle D. 'Violence is Not Part of Our Job': A Thematic Analysis of Psychiatric Mental Health Nurses' Experiences of Patient Assaults from a New Zealand Perspective Issues in Mental Health Nursing. 2014; 35: 647-655. PMid: 25162186. https: //doi.org/10.3109/01612840.2014.892552

[22] Olashore AA, Akanni OO, Ogundipe RM, et al. Physical violence against health staff by mentally ill patients at a psychiatric hospital in Botswana. BMC Health Serv Res. 2018; 18(1): 362. https://doi.org/10.1186/s12913-018-3187-6

[23] Llor-Esteban B, Mu-oz MS, Hernández JAR, et al. User violence towards nursing professionals in mental health services and emergency 
units. The European Journal of Psychology Applied to Legal Context. 2016.

[24] Chapman R, Styles I, Perry L, et al. Nurses' experience of adjusting to workplace violence: a theory of adaptation. Int J Ment Health Nurs. 2010; 19(3): 186-194. PMid: 20550642. https: //doi.org/10.1111/j.1447-0349.2009.00663.x

[25] Brown RG, Anderson S, Brunt B, et al. Workplace Violence Training Using Simulation. Am J Nurs. 2018; 118(10): 56-68. PMid: 30260888. https://doi.org/10.1097/01.NAJ.00005 46382.12045 .54

[26] Brous E. Workplace Violence. Am J Nurs. 2018; 118(10): 51-55. PMid: 30260887. https://doi.org/10.1097/01.NAJ.00005 46381.04422 .55

[27] Magnavita N. Violence prevention in a small-scale psychiatric unit: program planning and evaluation. Int J Occup Environ Health. 2011;
17(4): 336-344. PMid: 22069932. https://doi.org/10.1179/ oeh.2011.17.4.336

[28] Beryl R, Davies J, Völlm B. Lived experience of working with female patients in a high-secure mental health setting. Int J Ment Health Nurs. 2018; 27(1): 82-91. PMid: 27982497. https ://doi .org/10 $.1111 /$ inm. 12297

[29] Itzhaki M, Peles-Bortz A, Kostistky H, et al. Exposure of mental health nurses to violence associated with job stress, life satisfaction, staff resilience, and post-traumatic growth. Int J Ment Health Nurs. 2015; 24(5): 403-412. PMid: 26257307. https: //doi.org/10.1111/inm.12151

[30] Itzhaki M, Bluvstein I, Peles AB, et al. Mental Health Nurse's Exposure to Workplace Violence Leads to Job Stress, Which Leads to Reduced Professional Quality of Life. Front Psychiatry. 2018; 9: 59. PMid: 29535652. https ://doi.org/10.3389/fpsyt. 2018 .00059 